\title{
Career Planning and the Special Librarian A Selective Bibliography
}

\author{
by Marlis Hubbard and Jennifer Tinline
}

This bibliography is aimed at information professionals at all stages of career development who wish to achieve job satisfaction. However, it will be of particular value to two groups: new graduates and those seeking to make changes in their careers.

For both groups, career planning publications will help them to explore the multitude of career paths available to them. Such publications include information on occupational choices, working conditions, the employment outlook, job search techniques and placement sources.

As well, for experienced librarians engaged in moving onward or upward there are books and articles on sought-after competences, interpersonal networking, leadership skills and success strategies.

\section{Organization}

To meet the needs of the aforementioned groups, the bibliography is divided into two sections: Career Planning and Career Development. Entries are arranged alphabetically by title.

\section{Methodology}

Citations were selectively compiled from Concordia University Career Library's in-house database on INMAGIC PLUS (Version 1.0,1992) and from DIALOG Information Services Online using LISA (file 61), ERIC (file 1) and INFORMATION SCIENCE ABSTRACTS (file 202). Searches were performed in December 1992.

The bibliography is not meant to be exhaustive but is meant to illustrate the broad range of materials available on career planning and development. With respect to criteria for inclusion, only citations on career planning, professional development and job satisfaction for special librarians were selected. The citations were limited to journal articles and monographs in the English language with a publication date of 1986 or later.

\section{Career Planning}

Career As a Special Librarian. Chicago, IL: Institute for Research, 1990. Research no. 209. 24 p.

Provides an introduction to special librarianship and a description of job responsibilities, education, earnings and job opportunities. Features job sketches written by several librarians.
Careers in SpecialLibraries. Washington, DC: Special Libraries Association, 1989. $11 \mathrm{p}$.

Addresses concems of those in the midst of making career decisions. Classifies special librarianship into the fields of social sciences, arts, communications and business as well as the sciences (biomedical, earth, environmental, physical and applied).

"Charting a Career Path in the Information Professions." Kong, Leslie M. and R. A. H. Goodfellow. College and Research Libraries. v. 49, no. 3 (May 1988) p.207-216.

Presents a career stage model that will enable librarians to examine and take control of their careers. Elements of the model include primary roles, major psychological issues, required competencies and strategies to obtain competencies. Also outlines four stages of career development: apprentice, colleague, mentor and sponsor.

"Getting a Job: Tips and Techniques." Excerpted from SLA's Guide to Career Opportunities. Washington, DC: Special Libraries Association, n.d. $10 \mathrm{p}$.

Aimed at SLA's unemployed members, this item describes employment resources. Among them are telephone joblines, on-line job listings, employment services and placement and executive search firms.

\section{Guide to Career Opportunities for Special Librarians and} Information Professionals 1991: An SLA Information Kit. Washington, DC: Special Libraries Association, 1991. $64 \mathrm{p}$.

Introduces the profession and summarizes SLA's career and employment services. Includes articles on career development and resume/interview preparation.

Guide to Library Placement Sources. Myers, Margaret. Chicago, IL: American Library Association, 1990.16 p.

One of several career planning publications produced by the American Library Association. Among sources covered are library joblines, specialized library associations and groups, state library agencies and federal library jobs. Presents 
useful tips on job hunting, overseas employment and job exchanges.

Infopreneurs: Turning Data into Dollars. Weitzen, H. Skip. New York: John Wiley and Sons, 1988. 228 p.

Intended for aspiring information entrepreneurs. Offers suggestions on how to turn information technology into a marketable resource and on how to manage a successful business.

\section{Information For Sale: How to Start and Operate Your Data} Research Service. Everett, John H, and Elizabeth Powell Crowe, 1st ed. Blue Ridge Summit, PA: TAB, 1988. $178 \mathrm{p}$.

Directed toward those wishing to start an information service/brokerage and presents advice from those in the business.

Librarian (Special). Toronto, Ontario: Guidance Centre, Ontario Institute for Studies in Education, 1991. 4 p.

Briefly summarizes special librarianship by providing concise facts on working conditions, qualifications and the employment outlook.

"Librarians and Libraries in the 1990s: Gloom and Doom, or Fame and a Different Game." Regan, Muriel. Special Libraries. v. 78, no. 4 (Fall 1987) p. 295-298.

Discusses the prevailing shift in the profession from librarian to information manager. Stresses the necessity for savvy librarians to spiff up their image, adapt to new technologies, embrace career planning, encourage changes in library school education and ensure the quality of information delivered to users.

Opportunities inLibrary and Information Science Careers. Heim, Kathleen and Margaret Myers. Lincolnwood, IL: VGM Career Horizons, 1992. 145 p.

Provides a broad overview of the field and offers information useful for career planning and job hunting.

\section{Career Development}

The Achievement Factors: Candid Interviews with Some of the Most SuccessfulPeopleofOur Time. Griessman, B. Eugene. San Marcos, CA: Slawson Communications, 1990. 310 p.

Although not specifically written for information professionals, deals with factors conducive to success in any field. Based on interviews with highly successful individuals.
"Achievement Motivation." Tilley, Christine M. International Library Review. v. 21, no. 3 (July 1989) p. 279-287.

Reports the results of a study meant to ascertain why women obtain leadership positions less often than men. Graduating female librarians were questioned to examine some of the factors that might inhibit achievement-motivated behaviour.

"Careers and the Occupational Image." Slater, Margaret. Journal of Information Science. v. 13, no. 6 (1987) p. 335-342.

Urges librarians to improve their "collective occupational image", which the author maintains currently holds professionals back. Offers insight into how information professionals might improve this image.

Future Competencies of the Information Professional. Washington, DC: Special Libraries Association, 1991.

Compiles papers presented on June 13,1989 at a Special Libraries Association Professional Development Committee conference. Authors, representing a variety of types and sizes of libraries, inform readers of the knowledge, skills and attitudes likely to be sought by future employers.

"Interpersonal Networking: It Is Who You Know." St. Clair, Guy. Special Libraries. v. 80, no. 2 (Spring 1989) p. 107112.

Illustrates how informal networking helps librarians offer the best possible service and also helps them to develop professionally. Details how professional associations, mentors, continuing education programs, librarians and nonlibrarian colleagues all provide networking opportunities.

"Leadership Can Be Learned and Personal/Career Strategies Plan or Making Things Happen through Self-Leadership." DiMattia, Susan S. Special Libraries. v. 81, no.2 (Spring 1990) p. 126-135.

Discusses desirable leadership qualities such as motivation, focused energy, commitment, creativity, innovation and flexibility. Elaborates on factors which prevent librarians from seeing themselves as leaders and outlines a step-bystep plan for them to achieve careersatisfaction through selfleadership.

The Librarians' Self-Starter: 100's of Questions To Challenge Your Thinking about Your Image, the Profession's Image, Your Job and Your Future, A Manual for Concerned Librarians. Paul, Meg and Jennifer Evans. Camberwell, Australia: Freelance Library and Information Services Pty., 1988.29p. 
"The Special Librarian as a Front Runner: Running Fast, Running Hard, Running Ahead." Regan, Muriel. Special Libraries. v.81, no.2 (Spring 1990). p. 92-96.

Proposes that special librarians must market themselves within their organizations to remain key players. Emphasizes the necessity for thinking strategically, shedding one's modesty, downplaying clerical roles and broadcasting one's expertise.

"Strategies for Success (Or Opportunities Galore)." Eddison, Betty. Special Libraries. v. 81, no. 2 (Spring 1990). p. 111118.

Successful information professionals share their strategies for gaining recognition in the field.

\section{Conclusion}

Career planning and development are essential for both new and experienced librarians, especially if they expect to achieve a substantial degree of career satisfaction. For novices, career planning offers a firm foundation for choosingoptions consistent with interests and abilities. For experienced librarians, career planning and development afford possibilities for renewal and revival as key opportunities present themselves.

Information professionals cannot afford to be passive about their careers, as implied by Susan S. DiMattia. "At some point in your life, it is vital to take a hard, cold, close look at where and what you are compared to where you thought you would be and what you have always secretly (or not so secretly) dreamed of being or doing." ' Moreover, librarians must take stock of their dreams and their goals at regular intervals throughout their careers to ensure that they remain on target in attaining their goals.

In summary, librarians must uncover the path to their own job satisfaction by enlarging their awareness of career possibilities. They must further ensure success in their chosen specialities by setting clear career goals. Finally, they must ensure the attainment of such goals by developing their own competencies, perceiving opportunities and seizing them. ${ }^{2}$

It is the hope of the authors that this bibliography will help information specialists get started in exploring their many career options and career strategies in order to achieve the greatest amount of job satisfaction possible.

\section{References}

1. Susan S. DiMattia, "Personal/Career Strategic Plan or Making Things Happen through Self-Leadership," Special Libraries 81 (Spring 1990): 132.
2. B. Eugene Griessman, The Achievement Factors: Candid Interviews With Some of the Most Successful People of Our Time (San Marcos, CA: Slawson Communications, 1990) 